Historic, Archive Document

Do not assume content reflects current scientific knowledge, policies, or practices. 



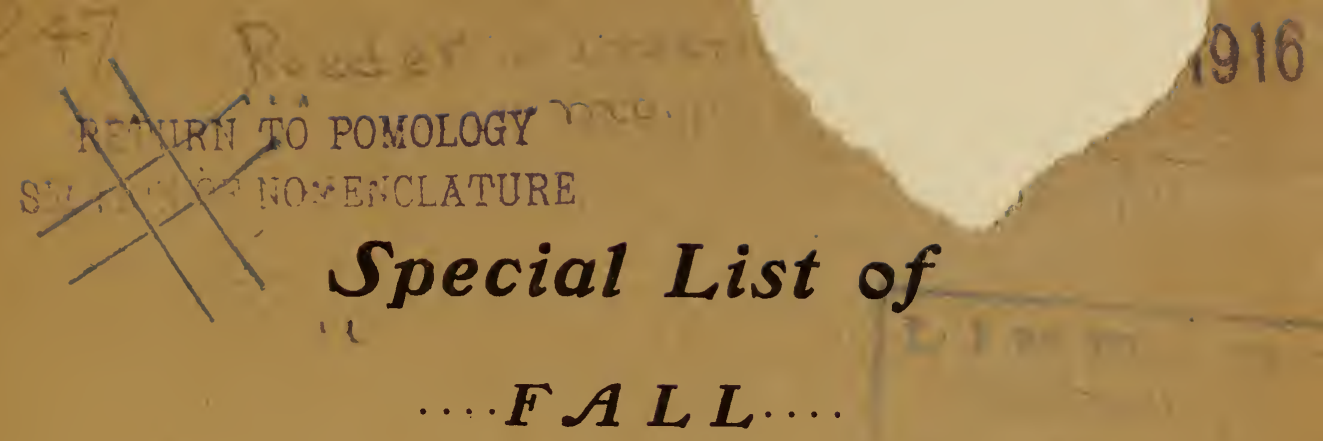

\section{Bearing Strawberries}

The past few years have convinced us that the fall bearing strawberries are with us to stay, and have established themselves as a most delightful and protitable acquisition that the berry world has known-an entirely new species that produces berries from May until November. After careful experimenting with them we have decided upon these four varities as the best: Americus, Progressive, Superb and lowa.

AMERICUS (per) one of the best known and most thrifty growers of the fall bearing varities. Good, heavy root system, foliage large, a good plant maker. Plants are strong, healthy and (leep rooters. 'Ihe fruit is tirm, medium to large, light red, heart shape, of tine texture, quality extra good, fruit stems strong, holding berries from the ground. Young runner plants begin to bear as soon as they begin to root. A valuable variety. Price 50 cents per $12 ; \$ 3.50$ per 100 .

PROGRESSIVE-This is one of the very best of the everbearing sorts. Plants medium sized, resembling Dunlap; has a strong, healthy folinge, good root system, good plant maker. Fruit is of good, medium size, color, deep red inside and out, quite firm, quality rich and'sweet. We think this is one of the best ever-bear. ing sorts. Price 50 cents per $12 ; \$ 3.50$ per 100 .

SUPERB-(per). Mr. Samuel Cooper of New York, the originator of the Superb, considers it the best fall bearing strawberry to date. A healthy grower that makes runners freely. Superb berries are larger than other varities and of better quality and appearance. The fruit of Superb is large, round, rich, dark colored, glossy, attractive and smooth, and ripens all over at once. Price 75 cents per $12 ; \$ 4.00$ per 100 .

IOWA (per). Introduced by Mr. Crawford of Ohio, well known as an able anthority on strawberries. 'This is a strong plant maker, vigorous grower, productive. 'The berries are large, nearly ronnd, of fine appearance and quality. The flavor is extra fine. Price 75 cents per $12 ; \$ 4.00$ per 100 . 


\section{TESTIMON I A L S}

We want you to carefully read these testimonials. We think they all speak for themselves. We would kindly ask fou to give us at least a trial order. We will treat you right. All our stock is sold under a guarantee. If it is not as represented we cheerfully refund the mroney. Give us your order now and trust us for the rest. Yours truly,

\section{THE ROEDER NURSERIES,}

W. H. Roeder, Proprietor.

Roeler Nurseries:

Proctun West, Va., Dec. 8, 1913

Received trees O. K. Yours truly,

Wm. SrHAFER

Roeder Nurseries, Osceola, Mo. $\quad$ Farrfield, Iowa, April 1, 1914

'rees arrived today in good condition. Many thanks for the extrat tree, as I have none of that sort. Yours truly,

W. H. RA'TC'TIFF

Roeder Nurseries, Osceola, Mo.

Springtield, Ill., Dec. 3,1913

Dear Sirs: I receivel fruit trees in good condition and I am pleased with them. I planted them the day after their arrival. I thank you for your prompt lelivery. I am you's, W. P. JUNES

Washingtou, Mo., March 21, 1914

Dear Sirs: Recoived the seren apple trees I ordered from you in tirst class condition. Yours Truly,

\section{I.EONARD VALENTINE}

W. H. Roeller:

1)elia, Colo., April 6, 1914

1)ear Sirs: Received plants April 4 in good condition and all () K. Truly Yours,

CHAS. 'T. READ

Liberal Mo., March 28, 1914

Dear Sirs: I received the grape vines and blackbery plants in good eondition. Yours Truly,

G. F. MOBLEY

New Castle, KJ., May 28, 1914

Dear Sirs: I thought that I would write you those trees are living fine, you can't beat them. Please mail me your catalogue. I want to see what you have this fall.

NICK MOORE

Adrian, Mo., April 3, 1914

Deal Sirs: Received trees. They arrived in good shape and am well pleased with them. Yours Respectfully,

C. D. 'THATCHER

Mr. W. H. Roeder:

Lemonville, Mo., April 2, 1914

Dear Sir. 'Trees received jesterday. They were all right and we thank you for so much care. We can recommend you to any one wanting information. Do not think we would order from any other nursery. I will send you your money with this the amount of $\$-$ due you. Respectfully wishing you gieat success, MRS. CHARLES RICE 